\title{
Comparative Growth Performance of Calves of Different Cattle Breeds Under a Feedlot Fattening System
}

Ijaz Ahmad', Muhammad Fiaz², Muhammad Nauman Manzoor ${ }^{3}$, Tanveer Ahmad ${ }^{2}$, Muhammad Yaqoob ${ }^{2}$ and Ik Hwan Jo ${ }^{4}$ ${ }^{1}$ Department of Agricultural Sciences, Allama Iqbal Open University, Islamabad, Pakistan, ${ }^{2}$ Department of Livestock Production and Management, Pir Mehr Ali Shah Arid Agriculture University Murree Road Shamsabad, Rawalpindi, Pakistan,

${ }^{3}$ Barani Livestock Production Research Institute Kherimurat, District Attock, Punjab, Pakistan, ${ }^{4}$ Department of Animal Resources, College of Life and Environmental Sciences, Daegu University, South Korea

\begin{abstract}
Male cattle calves $(n=24), 9-12$ months age, with an average body weight of $120 \pm 20 \mathrm{~kg}$ were fed total mixed rations (TMR) for 120 days to determine their growth performance. Animals were divided into four groups (six of each breed): Crossbred (Friesian $\times$ Sahiwal), Dhanni, Lohani, and Cholistani. The data obtained were analyzed using analysis of variance techniques under a completely randomized design. The average daily gain(ADG), feed efficiency (FE), and dressing percentage ranged from $639-892 \mathrm{~g} / \mathrm{d}, 0.105-0.155 \mathrm{~kg} / \mathrm{kg}$, and $51.2-51.5 \%$, respectively, in the different breeds. The ADG and FE did not differ between the Crossbred, Dhanni, and Lohani breeds, but these values were lower in Cholistani calves $(\mathrm{P}<0.05)$. The dressing percentage was similar in all breeds. The highest increase in body height was observed in Dhanni calves, but heart girth was obviously higher in Lohani calves. The feed cost per $\mathrm{kg}$ gain was higher for Cholistani calves but similar among Crossbred, Dhanni, and Lohani calves $(\mathrm{P}>0.05)$. In conclusion, Dhanni, Lohani, and Crossbred calves possess the promising potential for beef production under the rainfed (Barani) conditions of the Punjab.
\end{abstract}

(Key words : Growth, Calves, Fattening, Dhanni, Lohani, Cholistani)

\section{INTRODUCTION}

The livestock sector plays a substantive role in the national economy of Pakistan. This is evidenced by its contribution to the national GDP $(11.6 \%)$ and GDP in agricultural value (55.4\%) (GOP, 2012-13). Livestock provide valuable food commodities for humans, with gradual increases in their demand due to changing public consumption patterns and the increasing human population in the country. The demand for meat in the form of beef and mutton is fulfilled through the slaughtering of large and small ruminants (besides poultry birds). Quality beef is unavailable in the country, as most beef produced comes from culled animals, dairy male calves, and spent dairy animals. Young animals with a moderate body condition score (BCS) are occasionally slaughtered as well (e.g., during Eid-ul-Azha - a religious Muslim festival).

Pakistan is blessed with a variety of various breeds of different livestock species. The main breeds of cattle include:
Sahiwal, Red Sindhi, Tharri, Bhagnari, Dajal, Lohani, Dhanni, Cholistani, and Crossbred (Frisian $\times$ Sahiwal). The population of cattle in the country is considerable (6.6 million male calves; GOP, 2012). Unfortunately, the lifetime productivity of these animals is significantly low due to a poor growth rate, long dry periods, and calving interval (Jabbar et al., 2000). Calves are improperly reared, resulting in a poor growth rate $(415 \mathrm{~g} / \mathrm{d})$ at the age of one year, and a body weight of 70-100 $\mathrm{kg}$ having a 42-43 dressing percentage, resulting in improper fattening before their slaughter (Afzal et al., 2009). However, Ahmad et al. (2013) reported that a weight gain of $766 \mathrm{~g} /$ day could be achieved in cattle calves through improved feeding methods.

Due to the current state of beef production in the country, the present project was proposed to determine the growth performance of cattle calves from indigenous breeds raised in the arid zone, where scarce water and fodder are major issues.

* Corresponding author: Ik Hwan Jo, Department of Animal Resources, College of Life and Environmental Sciences, Daegu University, South Korea. Email: greunld@daegu.ac.kr 


\section{MATERIALS AND METHODS}

\section{Experimental animals and dietary treatments}

The proposed study was conducted at the Barani Livestock Production Research Institute (BLPRI) in Kherimurat (Attock District; Punjab, Pakistan). Twenty-four animals were selected for the feeding trial including six calves from each breed (Dhanni, Lohani, Cholistani, and crossbred (Friesian $\times$ Sahiwal)). The selected animals were allocated into four treatments: Group A, six calves from the Dhanni breed; Group B, six calves from Lohani breed; Group C, six calves from Cholistani breed; and Group D, six calves from crossbred (Friesian $\times$ Sahiwal). All animals had an approximately similar body weight $(120 \pm 20 \mathrm{~kg})$ and age (9-12 months). Before the trial all calves were weighed, properly tagged, and treated for internal and external parasites. All calves were kept in separate pens under identical conditions during the trial.

The calves were fed total mixed rations (TMR) containing about $12 \%$ crude protein (CP) and $67 \%$ total digestible nutrients (TDN) for 120 days (Table 1). The calves were individually fed daily in the morning and evening ad libitum, while leftover feed was reserved for the next morning. The body weight of the calves was recorded on a fortnightly basis. The average daily gain (ADG) was also calculated fortnightly by subtracting the initial weight from the final weight of animals and then dividing by the duration of the experiment (days). Feed efficiency was calculated by dividing weight gain by the feed quantity consumed. The feed cost per $\mathrm{kg}$ live weight gain was determined by dividing the cost of feed consumed by $\mathrm{kg}$ of live weight gain. The body measurements in centimeters (length, height, girth) were taken on a monthly basis. The gain in body height, length, and heart girth were recorded by subtracting initial values from final body measurements.

\section{Carcass evaluation}

Animals were slaughtered for carcass evaluation at the end of the experiment. For this purpose, animals were kept off feed overnight followed by their weighing and slaughter the next morning. The dressing percentage was determined by subtracting the dressed carcass weight from final live weight and then multiplying by 100 . The weight of blood, skin, trotter, head, gastrointestinal tract(GIT), and other offals
Table 1. Ingredient and nutrient composition for calves

\begin{tabular}{|c|c|}
\hline Ingredient & Inclusion level $(\%)$ \\
\hline Cotton seed Cake & 10 \\
\hline Maize gluten 30 & 05 \\
\hline Maize grain broken & 31 \\
\hline Wheat Bran & 12 \\
\hline Wheat Straw & 22 \\
\hline Molasses & 17 \\
\hline Urea & 1 \\
\hline Minerals mixture* & 2 \\
\hline Total & 100 \\
\hline CP (\%) & 12 \\
\hline TDN (\%) & 67 \\
\hline \multicolumn{2}{|c|}{ 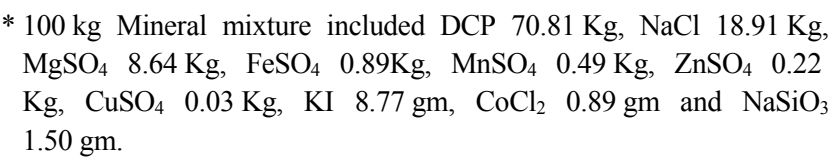 } \\
\hline
\end{tabular}

(heart, liver, lungs, kidneys, spleen, testes and mesenteric fat) were recorded and their respective percentage of the live body weight was calculated.

\section{Statistical analysis}

The collected data were analyzed using ANOVA under the Completely Randomized Design(CRD). The difference in mean between treatments was tested through Duncan's Multiple Range Test (Steel et al., 1997).

\section{RESULTS}

\section{Live performance}

The average daily gains (ADG) in calves of Crossbred, Dhanni, and Lohani breeds fed total mixed rations were similar ( $\mathrm{P}>0.05$; Table 2). However, $\mathrm{ADG}$ was lower in Cholistani calves compared to Crossbred and Dhanni calves $(\mathrm{P}<0.05)$ but similar to Lohani calves $(\mathrm{P}>0.05)$. The feed efficiency (FE) remained similar $(\mathrm{P}>0.05)$ among calves of Crossbred, Dhanni, and Lohani breeds; however, FE was lower in Cholistani calves (Table 2). The feed cost per $\mathrm{kg}$ live weight gain was lower inCrossbred, Dhanni, and Lohani calves $(\mathrm{P}<0.05)$ than Cholistani calves. However, the feed expenditure in feed cost per $\mathrm{kg}$ live weight gain was similar $(\mathrm{P}>0.05)$ among Crossbred, Dhanni, and Lohani calves. 
Table 2. Comparative average daily gain in calves from different cattle breeds

\begin{tabular}{ccccc}
\hline \multirow{2}{*}{ Parameter (s) } & \multicolumn{4}{c}{ Treatments groups } \\
\cline { 2 - 4 } & Dhanni & Lohani & Cholistani & Crossbred \\
\hline \hline Average daily gain $(\mathrm{g} / \mathrm{d})$ & $884.7 \pm 75^{\mathrm{a}}$ & $752.6 \pm 10^{\mathrm{ab}}$ & $639.3 \pm 25^{\mathrm{b}}$ & $892.4 \pm 56^{\mathrm{a}}$ \\
Feed efficiency (kg/kg) & $0.152 \pm 0.005^{\mathrm{a}}$ & $0.133 \pm 0.001^{\mathrm{a}}$ & $0.105 \pm 0.002^{\mathrm{b}}$ & $0.155 \pm 0.011^{\mathrm{a}}$ \\
Feed cost per kg live weight gain & $119 \pm 03^{\mathrm{a}}$ & $119 \pm 04^{\mathrm{a}}$ & $144 \pm 02^{\mathrm{b}}$ & $118 \pm 10^{\mathrm{a}}$ \\
Dressing percentage (\%) & $51.40 \pm 0.166$ & $51.48 \pm 0.25$ & $51.21 \pm 0.23$ & $51.5 \pm 0.23$ \\
\hline
\end{tabular}

${ }^{\mathrm{ab}}$ Means in a row and with no common superscript differ significantly $(\mathrm{P}<0.05)$.

Table 3. Comparative body structural measurements in calves of different cattle breeds

\begin{tabular}{ccccc}
\hline \multirow{2}{*}{ Parameters (s) } & \multicolumn{4}{c}{ Treatments groups } \\
\cline { 2 - 4 } & Dhanni & Lohani & Cholistani & Crossbred \\
\hline \hline Body length $(\mathrm{cm})$ & $18.5 \pm 5.4$ & $17.2 \pm 1.1$ & $18 \pm 04$ & $14.2 \pm 2.5$ \\
Body height $(\mathrm{cm})$ & $19.6 \pm 2.1^{\mathrm{a}}$ & $10.2 \pm 0.8^{\mathrm{b}}$ & $10 \pm 01^{\mathrm{b}}$ & $14 \pm 1.1^{\mathrm{b}}$ \\
Heart girth $(\mathrm{cm})$ & $18.8 \pm 2.5^{\mathrm{ab}}$ & $26 \pm 1.3^{\mathrm{a}}$ & $18 \pm 3.7^{\mathrm{ab}}$ & $14.8 \pm 2.85^{\mathrm{b}}$ \\
\hline
\end{tabular}

${ }^{\mathrm{ab}}$ Means in a row and with no common superscript differ significantly $(\mathrm{P}<0.05)$.

Table 4. Comparative average weight of body components as percentage of live body weight in calves of different cattle breeds under feed lot fattening

\begin{tabular}{cccccc}
\hline \multirow{2}{*}{ Parameters } & \multicolumn{5}{c}{ Treatments groups } \\
\cline { 2 - 6 } & Dhanni & Lohani & Cholistani & Crossbred & Overall \\
\hline \hline Average Live weight (Kg) & 229 & 204 & 217 & 254 & 226 \\
Blood (\%) & 2.2 & 2.5 & 2.1 & 3 & 2.5 \\
Skin (\%) & 8.6 & 9 & 8.5 & 9.2 & 9.0 \\
Trotter (\%) & 2.2 & 1.8 & 2.3 & 1.7 & 2.0 \\
Head (\%) & 4.4 & 4.2 & 4.5 & 4.7 & 4.5 \\
GIT (\%) & 5.6 & 5.2 & 5.3 & 5.7 & 5.5 \\
\hline
\end{tabular}

Various parameters pertaining to an increase in body structural measurements were determined (Table 3). The increase in body length during the experimental period was similar among calves of all breeds $(\mathrm{P}<0.05)$. Only Dhanni calves exhibited increases in body height $(\mathrm{P}<0.05)$. However, heart girth increases in Lohani calves were higher than those in crossbred calves $(\mathrm{P}<0.05)$ but similar to those in Dhanni and Cholistani calves $(\mathrm{P}<0.05)$.

\section{Dressing percentage and offals weight}

The dressing percentage was similar $(\mathrm{P}>0.05)$ between calves of Crossbred, Dhanni, Lohani, and Cholistani breeds
(Table 2). There were non-significant differences between breeds in terms of average weight of offals as a percentage of live body weight (Table 4). Relative to live body weight, the overall percentages were: blood $2.5 \%$, skin $9 \%$, trotter $2 \%$, head $4.5 \%$ and GIT $5.5 \%$.

\section{DISCUSSION}

\section{Live performance}

Dhanni calves native to the rainfed (Barani) area showed promising beef potential in terms of $\mathrm{ADG}$ and were comparable to Crossbred and Lohani calves. The better 
performance of Dhanni calves in the rainfed area could be due to their comparatively better acclimatization to the area. The data indicated that the beef production potential of Lohani calves in terms of ADG was similar to that of Dhanni and Crossbred calves. In contrast to this study, Ali et al. (2008) reported that Cholistani calves performed better in terms of $\mathrm{ADG}(690 \mathrm{~g} / \mathrm{d})$. This might be due to differences in the environmental conditions applied.

The findings of Pasha and Jabbar (1995) regarding the ADG of native breeds (Nondescript and Dajal) were similar to the results of this study. The range of $\mathrm{ADG}$ in calves belonging to Nondescript, Cholistani, and Dajal breeds (746 to $840 \mathrm{~g} / \mathrm{d}$ ) corresponded to that in the present trial (639 to $892 \mathrm{~g} / \mathrm{d})$. In another study, Jabbar et al. (2009) affirmed the $\operatorname{ADG}(899 \mathrm{~g} / \mathrm{d})$ in Crossbred calves to values in the present study $(892 \mathrm{~g} / \mathrm{d})$.

The pattern of feed efficiency among different breeds of calves in this study was similar in terms of ADG. Dhanni and Lohani calves were equally efficient to crossbred calves in converting feed into body biomass. However, the feed efficiency of the Cholistani breed was lower compared to calves of other breeds. This suboptimal performance could be due to the poor acclimatization of Cholistani calves in the Barani area (Pothowar region) as Cholistani cattle belong to the Cholistan desert in the Bahawalpur District of Punjab (Mason, 1996). Jabbar et al. (2009) reported a similar result for the FCR of Cholistani calves but Ali et al. (2008) reported a higher feed efficiency (0.123) compared to this study (0.105) in Cholistani calves. The most likely reason for this difference is the different environment in which calves were kept within the Cholistan tract of Punjab.

The performance of Crossbred calves versus Dhanni and Lohani calves were very similar in terms of cost effectiveness for meat production under rainfed conditions. However, there was a comparatively higher feed cost for Cholistani calves that might be due to their lower feed efficiency. Skunmun et al. (2002) reported a higher feed cost/kg gain (58 Thai Baht or 175 Pak RS) in Crossbred calves compared to this study (39 Thai Baht or 118 Pak RS). The possible reason for this difference might be due to the different genetic makeup of the calves they examined (75\% Holstein Friesian and 25\% indigenous Thai cattle) under the hot and humid conditions of Thailand. Similarly, Jabbar et al. (2006) also reported different feeding costs (Pak RS $52 / \mathrm{kg}$ weight gain) in Crossbred (Friesian $\times$ Sahiwal) calves. This difference could be due to the 2.5 times lower price of feed during the calendar year of that study.

The dressing percentage was similar among calves in different groups in this study $(\mathrm{P}>0.05)$. The range for dressing percentage (51.2 to $52.2 \%)$ in this study agreed with the similar work of Jabbar et al. (2006). They reported a similar dressing percentage (51.5 to 52.3\%) in Crossbred (Friesian $\times$ Sahiwal) calves. However, the dressing percentages of native cattle breeds were lower than those in another study conducted by Jabbar et al. (2009). However, Pasha et al. (1988) reported similar dressing percentages in indigenous Nili Ravi buffalo calves. In another study, Purchas et al. (1997) also reported a higher dressing percentage in Crossbred calves (55\%) compared to this study (51.5\%). The most likely reason for this variation is the arid and harsh conditions used in this study, in which feed and water shortage were quite common.

The highest increase in body height was observed in Dhanni calves fed through feedlot fattening from 12 to 16 months of age. Similarly, the heart girth of Lohani calves during the same time period was highest, followed by Dhanni, Cholistani, and Crossbred calves, respectively. An obviously higher increase in heart girth in Lohani calves compared to other breeds could be due to their comparatively faster tissue growth, as reported by Blackmore et al. (1995). They divided their linear measurements into skeletal and tissue measurements. The tissue measurements included heart girth, chest depth, and hip widths. Further studies need to ascertain the relationship between various linear body measurements in indigenous breeds of cattle.

\section{CONCLUSION}

In conclusion, Dhanni, Lohani, and Crossbred calves possess the promising potential for beef production under the rainfed (Barani) conditions of the Punjab.

\section{ACKNOWLEDGEMENTS}

The authors are very grateful to Mr. Muhammad Mukhtar (Livestock Officer), Mr. Muhammad Aslam (Deputy Director), Mr. Mian Muhammad Siddiq (Research Officer), Mr. Mushtaq Ahmad (Assistant Research Officer), Mr. Muhammad Younas (Veterinary Officer), Mr. Sadaqat (Veterinary Assistant) and Feed Mill staff at the Barani Livestock Production Research Institute (BLPRI) in the Kherimurat (Attock District; Punjab, Pakistan) for their kind supply of research material and 
facilities. This study was funded through the Director of the BLPRI in Kherimurat, Pakistan, and the Cooperative Research Program for Agriculture Science \& Technology Development (Project No. PJ007800062013) of the Rural Development Administration, Republic of Korea.

\section{REFERENCES}

Afzal, M., Anwar, M., Mirza, M. A. and Andrabi, S. M. H. 2009. Comparison of growth rate of male buffalo calves under open grazing and stall feeding systems. Pakistan J. Nutr., 8:187188.

Ahmad, S., Haq, Z. U., Jabbar, G., Muhammad, Y., Sultan, S., Ihsanullah and Khan, D. 2013. Growth Performance of Calves in Khyber Pakhtunkhwa, Pakistan. J. Anim. And Plant Sci., 23(1 Suppl.): 98-102.

Ali, I., Farooq, U., Hameed, S., Shehzad, F., Khan, F. S. and Tausif, M. A. Performance of Cholistani male cattle calves fed fattening ration under local climatic conditions. Pak. J. Agri. Sci., 45(2):184-189.

Blackmore, D. W., McGulliard, L. D. and Lush, J. L. 1995. Genetic relationship between body measurements at three ages in Holstein. J. Dairy Sci. 41:1045.

GOP (Government of Pakistan). 2012-13. Economic Survey of Pakistan. Government of Pakistan. Ministry of Finance. Economic Adviser's Wing, Islamabad.

Jabbar, M. A., Rehman, A., Fiaz, M., Gilani, A. H., Pasha, T. N. and Maraghzani, I. B. 2009. Comparative performance of calves of buffalo and different breeds of cattle on feedlot fattening. Pakistan J. Zool. Suppl. Ser., No. 9: 401-404.

Jabbar, M. A., Anjum, M. I., Rehman, S. and Shahzad. W. 2006. Comparative efficiency of sunflower and cottonseed cake in the feed of crossbred calves for meat production. Pak. Vet. J., 26:126-128.

Jabbar, M. A., Hussain, M. and Pasha, T. N. 2000. Effect of different dietary energy levels on growth and onset of sexual maturity in Sahiwal heifers. 21st Annual Report. Livestock Prod. Res. Inst., Bahadurnagar, Okara, Pakistan: 76-77.

Mason, I. L. 1996. A world dictionary of livestock breeds, types and varieties. $4^{\text {th }}$ Ed. C.A.B. International. 273p.

Pasha, T. N. and Jabbar, M. A. 1994-95. Comparative meat production potentials and carcass evaluations of buffalo and different breeds of cattle calves. Annual Report Univ. Agri. Faisalabad (Pakistan). 214-215.

Pasha, T. N., Malik, M. Y. and Jabbar, M. A. 1988. Comparative meat production potential of buffalo and crossbred calves. Pakistan Vet. J., 8:74-76.

Pasha, T. N. 1987. Comparative feed lot fattening and carcass evaluation of Sahiwal and Buffalo calves. $9^{\text {th }}$ Annual Report, Livestock Prod. Res. Inst. Bahadur Nagar Okara (Pakistan): 132-136.

Purchas, R. W., Hartley, D. G. and Xun, Y. 1997. An evaluation of the growth performance, carcass characteristics and meat quality of Sahiwal-Friesian cross bulls. New Zealand J. Agri. Res., 40:497-506.

Skunmun, P., Chantalakhana, C., Pungchai, R., Poondusit, T. and Prucsasri, P. 2002. Comparative Feeding of Male Dairy, Beef Cattle and Swamp Buffalo: Economics of Beef Production. Asian-Aust. J. Anim. Sci., 15(6):878-883.

Steel, R. G. D, Torrie, J. H. and Dickie, D. A. 1997. Principles and Procedures of Statistics-a Biometrical Approach. (3rd Ed). McGraw-Hill Publishing Company. Toronto, Canada.

(Received Sep. 25, 2013; Accepted Oct. 14, 2013) 